\title{
Importance of Evaluation of Urinary Iron and Transferrin in the Common Histopathological Types of Idiopathic Nephrotic Syndrome in Children
}

\author{
Ghada A. Abdel-Aleem, Abu El-Hana N*, Zoair A*, Abd El-Hamid T** \\ Medical Biochemistry Department, Pediatrics Department*, \\ Pathology Department**, Faculty of Medicine, Tanta University
}

\begin{abstract}
Nephrosis with minimal glomerular changes, minimal change nephrotic syndrome (MCNS) and focal-segmental glomerulosclerosis (FSGS) are by far the predominant causes of idiopathic nephrotic syndrome (INS). Recently there is an increasing interest in the role of iron in the causation of renal injury and deterioration of renal function in adults and children with nephrotic syndrome. Urinary excretion of $N$ acetyl- $\beta$-D-glucosaminidase (NAG) may be useful as a marker of tubular dysfunction and damage in idiopathic nephrotic syndrome (INS) which often characterizes steroid-resistant children. The present study was carried out to estimate the level of serum and urinary iron and transferrin to evaluate the effect of their excretion in the development of anemia in nephrotic children, also to clarify the prognostic value of urinary iron according to the histopathological type of the disease. The present work was also devoted to assess the role of immune system in the pathogenesis of idiopathic nephrotic syndrome by determination of serum $\beta_{2}$-microglobulin and serum and urinary neopterin. The degree of tubular damage in the most common histopathological types of idiopathic nephrotic syndrome was assessed by estimation of urinary $N$-acetyl- $\beta$-D-glucosaminidase enzyme (NAG). The study was conducted on 45 children who were grouped as control group and nephrotic children group which was subdivided into two subgroups: minimal-change nephrotic syndrome (MCNS) group and segmental glomerulosclerosis (FSGS) group. The study included fifteen in each group with no significant difference in the mean age and sex between the three studied groups. All children in the study were subjected to thorough history taking, complete physical examination and laboratory investigations which included serum and urinary iron excretion per 24 hours, serum and urinary transferrin excretion per 24 hours, serum ferritin, total iron binding capacity, serum and urinary neopterin excretion per 24 hours, serum $\beta 2$-microglobulin, urinary $N$-acetyl- $\beta$ - $D$ glucosaminidase enzyme (NAG) excretion per 24 hours, stool analysis for occult blood to exclude gastrointestinal bleeding and finally renal biopsy was done for all nephrotic children enrolled in the study for histopathological examination. The results of our study showed that idiopathic nephrotic syndrome (INS) is associated with normocytic normochromic anemia despite the increased urinary losses of iron and transferrin. Also, the results of this study showed that both serum neopterin and $\beta_{2}$-microglobulin were significantly higher in both nephrotic groups than the control subjects. Serum neopterin level was significantly higher in FSGS group than MCNS
\end{abstract}


group with no significant difference of serum $\beta_{2}$-microglobulin between MCNS and FSGS groups. It could be concluded that estimation of urinary proteins, urinary iron and urinary NAG could be important for follow up and prediction of the prognosis in children with INS.

\section{INTRODUCTION}

Idiopathic nephrotic syndrome is primarily a pediatric disorder as it is 15 times more common in children than adults. The characteristic features of nephrotic syndrome are heavy proteinuria $(>3.5 \mathrm{~g} / 24 \mathrm{hr}$ in adults or $40 \mathrm{mg} / \mathrm{m}^{2} / \mathrm{hr}$ in children), hypoalbuminemia $(<2.5 \mathrm{~g} / \mathrm{dL})$, edema, hyperlipidemia $^{(1)}$. There are three distinct histological variants of primary idiopathic nephrotic syndrome: minimal-change nephrotic syndrome (MCNS), focal segmental glomerulosclerosis (FSGS), and membranous nephropathy. MCNS and FSGS may represent opposite ends of one pathophysiological process or distinct disease entities. By contrast, membranous nephropathy is a disease associated with prominent immune complex deposits located between glomerular podocytes and the glomerular basement membrane, and is not common in children ${ }^{(2)}$.

Iron serves as either an electron donor (ferrous or $\mathrm{Fe}^{2+}$ ) or electron acceptor (Ferric or $\mathrm{Fe}^{3+}$ ) element. Convenient interconvertibility of that element between the two redox states, together with its overabundance in nature, has made iron a key player in a wide array of biochemical reactions ${ }^{(3)}$. Paradoxically, the same redox reactions responsible for the vital role of iron in various biochemical functions can be a potential source of serious cytotoxicity and tissue injury. However, a group of highly specialized chelating molecules and processes have evolved for the absorption, transport and storage of iron to preserve solubility and prevent iron-mediated free radical generation. Under normal conditions, these ironcomplexing compounds eliminate free iron from intracellular and extracellular compartments ${ }^{(3)}$. Transferrin belongs to the ironbinding protein family. It is an $80-\mathrm{kDa}$ monomeric glycoprotein. It consists of two homologous domains, each possessing a binding site for a ferric iron atom. Transferrin is synthesized by the liver and secreted into the circulation and extravascular space. Small amounts of transferrin are produced in testicles, spleen, brain, and kidneys ${ }^{(4)}$. Transferrin production is up regulated by hypoxia, iron deficiency, pregnancy, and estrogen and it is down regulated by malnutrition, inflammation, and iron overload $^{(5)}$.

Neopterin (D-erythro-1',2',3'trihydroxypropylpterin) is a pyrazino-pyrimidine. It is synthesized by monocyte/macrophages upon stimulation with the cytokine interferon-gamma and it serves as a diagnostic or prognostic marker in various immune-mediated clinical conditions. Measurement of neopterin concentrations in body fluids provides information about the cellular immune activation in humans under the control of $\mathrm{T}$ helper cells type1. High neopterin production is associated with increased production of reactive 
oxygen species elicited by the immune system ${ }^{(6)}$.

Idiopathic

nephrotic

syndrome might be secondary to a disorder of T-lymphocyte function ${ }^{(2)}$. The protective function of T-cells depends on their ability to recognize cells that are harboring pathogens or that have internalized pathogens or their products. T-cells do this by recognizing peptide fragments of pathogen-derived proteins in the form of complexes of peptides and major histocompatability complex (MHC) molecules on the cell surface. Because the generation of peptides from an intact antigen involves modification of the native protein, it is commonly referred to as antigen processing, whereas the display of the peptide at the cell surface by the MHC molecule is referred to as antigen presentation $^{(7)}$.

Beta-2 Microglobulin $\left(\beta_{2} \mathrm{M}\right)$ protein is a single polypeptide chain of low-molecular weight. It is freely filtered at the level of the glomerulus. Normally, a low level of $\beta_{2} \mathrm{M}$ is found in the urine because of a high capacity reabsorptive process in the proximal tubules. An elevation of urinary $\beta_{2} \mathrm{M}$ excretion reflects proximal tubular damage and might therefore more reliably reflects the presence of slight tubulointerstitial damage, which can be missed on biopsy ${ }^{(\mathbf{8})}$. A transient complex of MHC heavy chain and $\beta_{2} \mathrm{M}$ is known to be assembled into the transporters associated with antigen processing (TAP) molecule involving interaction with a number of chaperones. Binding of the processed peptide releases the class $\mathrm{I}-\beta_{2} \mathrm{M}$ complex on the cell surface. Absence of binding leads to degradation in the proteasome. Elevation of serum $\beta_{2} \mathrm{M}$ results from activation of the cellular immune system. Also, $\beta_{2} \mathrm{M}$ provides a sensitive indicator for monitoring therapy and disease course in patients with primary immunological disorders $^{(7)}$.

$\mathrm{N}$-acetyl- $\beta$-D-glucosaminidase (NAG), is a hydrolytic lysosomal enzyme that acts on glycosyl compound, oligosaccharides derived from hyaluronic acid with a molecular weight of 130 to $140 \mathrm{kDa}^{(9)}$. It is abundant in the body fluids, liver, lung and organs with high rates of mucoid turnover as the spleen and testicles $^{(\mathbf{1 0})}$. High concentrations are particularly found in the kidney, where NAG is located mainly in the lysosomal fraction of the renal proximal tubular cells, with a small amount in the microsomal fraction ${ }^{(9)}$. Due to its high molecular weight, it does not pass normally through the glomerulus and hence urinary NAG comes from the renal tubular cells secretion. NAG excretion in urine proceeds at low but detectable levels and is expressed as a ratio to urinary creatinine which is relatively constant throughout the day ${ }^{(\mathbf{1 0})}$.

\section{PATIENTS \& METHODS}

\section{Patients:}

The present study was carried out on forty five children. They were divided into two groups; the control group formed of fifteen healthy children (ten males and five females) without any history of renal disease, connective tissue disease, recent blood transfusion, severe allergies, or use of steroid medications which might affect immunologic parameters under 
investigations. The nephrotic children group formed of thirty children with idiopathic nephrotic syndrome with multiple relapses; they were selected from the Pediatrics Department Tanta University Hospital. They were diagnosed as nephrotic syndrome by the presence of heavy proteinuria $(>40$ $\mathrm{mg} / \mathrm{m}^{2} / \mathrm{hr}$. in children), hypoalbuminemia $\quad(<2.5 \mathrm{~g} / \mathrm{dL})$, oedema, and hyperlipidemia ${ }^{(\mathbf{1})}$. This group was subdivided into two subgroups, one included fifteen children (eight males and seven females) with minimal change nephrotic syndrome (MCNS). The other group formed of fifteen children (nine males and six females) with focal segmental glomerulosclerosis (FSGS), the diagnosis for both groups was done on histopathological basis after transcutaneous ultrasonographic guided-renal biopsy. The investigations were taken in relapse with exclusion of children with congenital anomalies of the kidney (e.g. polycystic kidney), children with nephrotic syndrome secondary to other cause (e.g. systemic lupus erythematosus, hypertension or diabetes mellitus), children with prolonged use of nephrotoxic drugs, and those with bleeding tendency or gastrointestinal bleeding. Parents of all patients and control groups gave an informed consent to participate in the study.

Methods:

All children in this study were subjected to thorough history taking, complete physical examination and laboratory investigations in the form of urinary proteins excretion per (24) hours (11), total serum proteins (12), serum albumin ${ }^{(13)}$, blood urea ${ }^{(14)}$ and serum creatinine ${ }^{(\mathbf{1 5})}$, total serum cholesterol $^{(\mathbf{1 6})}$ erythrocyte sedimentation rate, complete blood picture, serum and twenty four hours urinary transferrin by radial immunodiffusion method ${ }^{(17)}$, serum and twenty four hours urinary iron ${ }^{(\mathbf{1 8})}$, serum ferritin by ELISA using commercially available kits ${ }^{(19)}$, total iron binding capacity (TIBC) ${ }^{(20)}$, serum $\beta 2$ microglobulin $(\beta 2 \mathrm{M})$ by ELISA using commercially available kit was obtained from orgentic Diagnostika $\mathrm{GmbH}{ }^{(21)}$, serum and twenty four hours urinary neopterin by ELISA, commercial kit was obtained from IBL Immuno Biological Laboratories (USA) ${ }^{(22)}$ and twenty four hours urinary $\mathrm{N}$ - acetyl $\beta$-D- glucosaminidase (NAG) enzyme, commercial kit was obtained from Roche, Germany ${ }^{(23)}$. Transcutaneous ultrasonographic guided renal biopsy was done for all nephrotic children enrolled in this study, for histopathological examination to select the cases.

Statistical analysis:

Statistical presentation and analysis of the present study was conducted using the mean, standard deviation, student unpaired t-test, Chisquare test, and linear correlation coefficient and ANOVA test.

\section{RESULTS}

There was no significant difference in sex distribution between the control subjects, MCNS group and FSGS group $(\mathrm{P}>0.05)$ (table 1). There was no significant difference in age (years) between control subjects (9.5 $\pm 1.9)$, MCNS group $(9.5 \pm 2.4)$ and FSGS group $(9.6 \pm 2.2) \quad(\mathrm{P}>0.05)$ 
(table 2). There was no significant difference in weight $(\mathrm{kg})$ between control subjects $(28.6 \pm 5.8)$, MCNS group (29.3 \pm 7.3$)$ and FSGS group $(29.6 \pm 6.5)(\mathrm{P}>0.05)$. Also, there was no significant difference in duration of illness (months) between MCNS $(21.1 \pm 7)$ and FSGS groups $(22.5 \pm 6.8)$ $(\mathrm{P}>0.05) \quad$ (table 2). There was no significant difference in blood urea $(\mathrm{mg} / \mathrm{dL})$ and serum creatinine $(\mathrm{mg} / \mathrm{dL})$ between the three studied groups (control, MCNS and FSGS groups) $(\mathrm{P}>0.05) \quad$ (table 2). Erythrocyte sedimentation rate (ESR) was slightly higher in MCNS and FSGS groups than in control subjects but the difference was not significant
$(\mathrm{P}>0.05) \quad$ (table 2). Serum proteins $(\mathrm{g} / \mathrm{dL})$ and serum albumin $(\mathrm{g} / \mathrm{dL})$ were significantly lower in both $\operatorname{MCNS}(5.8 \pm 0.4),(2.4 \pm 0.3)$ and FSGS(5.17 \pm 0.46$),(1.86 \pm 0.14)$ groups than control subjects $(7 \pm 0.6),(4.5 \pm 0.4)$ respectively $(\mathrm{P}<0.001)$. Also, they were significantly lower in FSGS group than $\mathrm{MCNS}$ group $(\mathrm{P}<0.001)$ (table 2). Serum cholesterol (mg/dL) was significantly higher in both MCNS (404 \pm 127$)$ and FSGS $(388 \pm 108)$ groups than control subjects $\quad(142 \pm 29) \quad(\mathrm{P}<0.001)$. However, there was no significant difference in serum cholesterol between MCNS and FSGS groups $(\mathrm{P}>0.05)$ (table 2).

Table (1): Distribution of sex in control subjects and nephrotic children.

\begin{tabular}{|c|c|c|c|c|c|c|c|c|}
\hline \multirow[t]{2}{*}{$\overline{\text { Sex }}$} & \multicolumn{2}{|c|}{ Control $(n=15)$} & \multicolumn{2}{|c|}{$\operatorname{MCNS}(n=15)$} & \multicolumn{2}{|c|}{ FSGS $(n=15)$} & \multirow[t]{2}{*}{$\overline{X^{2}}$} & \multirow[t]{2}{*}{$\mathbf{P}$} \\
\hline & No. & $\%$ & No. & $\%$ & No. & $\%$ & & \\
\hline Male & 10 & 66.7 & 8 & 53.3 & 9 & 60 & 0.65 & $>0.05$ \\
\hline Female & 5 & 33.3 & 7 & 46.7 & 6 & 40 & & \\
\hline Total & 15 & 100 & 15 & 100.0 & 15 & 100 & & \\
\hline
\end{tabular}

$\mathrm{X}^{2}=$ Chi square. 
Bull. Egypt. Soc. Physiol. Sci. 29 (2) 2009

Abdel-Aleem et al.

Table (2): Age (years), weight (kg), duration of illness (months), Blood urea (mg/dL), serum creatinine (mg/dL), Erythrocyte sedimentation rate (ESR) $(\mathrm{mm})$, Serum proteins $(\mathrm{g} / \mathrm{dL})$, serum albumin $(\mathrm{g} / \mathrm{dL})$ and Serum cholesterol $(\mathrm{mg} / \mathrm{dL})$ in control subjects and nephrotic children.

\begin{tabular}{|c|c|c|c|c|c|c|c|c|}
\hline & Control group & MCNS group & FSGS group & F-TEST & & $\mathbf{P 1}$ & $\overline{\mathbf{P 2}}$ & $\overline{\mathbf{P 3}}$ \\
\hline \multicolumn{9}{|l|}{ Age (years): } \\
\hline Mean \pm SD & $9.5 \pm 1.9$ & $9.5 \pm 2.4$ & $9.6 \pm 2.2$ & \multirow{2}{*}{\multicolumn{2}{|c|}{0.005}} & \multirow[t]{2}{*}{$>0.05$} & \multirow[t]{2}{*}{$>0.05$} & \multirow[t]{2}{*}{$>0.05$} \\
\hline Range & $6-12.3$ & $6-12.8$ & $6-13$ & & & & & \\
\hline \multicolumn{9}{|l|}{ Weight (kg): } \\
\hline Mean \pm SD & $28.6 \pm 5.8$ & $29.3 \pm 7.3$ & $29.6 \pm 6.5$ & \multirow[t]{2}{*}{0.168} & & \multirow[t]{2}{*}{$>0.05$} & \multirow[t]{2}{*}{$>0.05$} & \multirow[t]{2}{*}{$>0.05$} \\
\hline Range & $19.6-37$ & $19.6-43$ & $19.6-42$ & & & & & \\
\hline \multicolumn{9}{|c|}{ Duration of illness (months) : } \\
\hline Mean \pm SD & & $21.1 \pm 7$ & $22.5 \pm 6.8$ & \multirow[t]{2}{*}{0.277} & & & & \multirow[t]{2}{*}{$>0.05$} \\
\hline Range & & $10-34$ & 10-31 & & & & & \\
\hline \multicolumn{9}{|l|}{ Blood urea (mg/dL): } \\
\hline Mean \pm SD & $\mathbf{1 2 . 3} \pm \mathbf{2 . 8}$ & $14 \pm 2.7$ & $14.3 \pm 3.2$ & \multirow[t]{2}{*}{2.028} & & \multirow[t]{2}{*}{$>0.05$} & $>0.05$ & \multirow[t]{2}{*}{$>0.05$} \\
\hline Range & $8-17$ & $10-18$ & $8-18$ & & & & & \\
\hline \multicolumn{9}{|c|}{ Serum creatinine $(\mathrm{mg} / \mathrm{dL})$ : } \\
\hline Mean \pm SD & \multirow{2}{*}{\begin{tabular}{|l|}
$0.53 \pm 0.13$ \\
$0.30-0.80$ \\
\end{tabular}} & $0.61 \pm 0.15$ & $\mathbf{0 . 6 9} \pm \mathbf{0 . 1 5}$ & \multirow{2}{*}{\multicolumn{2}{|c|}{4.48}} & \multirow[t]{2}{*}{$>0.05$} & \multirow[t]{2}{*}{$>0.05$} & \multirow[t]{2}{*}{$>0.05$} \\
\hline Range & & $0.40-0.90$ & $0.40-1$ & & & & & \\
\hline ESR (mm): & $2^{\text {nd }} h r$ & $2^{\text {nd }} h r$ & $2^{\text {nd }} \mathrm{hr}$ & \multirow{3}{*}{$\frac{\mathbf{1}^{\text {st }} \mathbf{h r}}{0.204}$} & \multirow{3}{*}{$\begin{array}{l}\mathbf{2}^{\mathbf{n d}} \mathbf{h r} \\
0.022\end{array}$} & & & \\
\hline Mean \pm SD & 20.13 & 11.13 & 20.20 & & & \multirow{3}{*}{$>0.05$} & & \\
\hline & \pm 3.11 & \pm 6.57 & \pm 7.98 & & & & \multirow[t]{2}{*}{$>0.05$} & \multirow[t]{2}{*}{$>0.05$} \\
\hline Range & $15-30$ & $13-40$ & $13-45$ & & & & & \\
\hline \multicolumn{9}{|l|}{ Serum proteins (g/dL): } \\
\hline Mean \pm SD & $7 \pm 0.6$ & $5.8 \pm 0.4$ & $5.17 \pm 0.46$ & 52.99 & & $<0.001$ & $<0.001$ & $<0.001$ \\
\hline Range & $6.2-8$ & $5.1-6.5$ & $4.3-5.9$ & & & & & \\
\hline Serum albumin $(\mathrm{g} / \mathrm{dL}$ & & & & & & & & \\
\hline Mean \pm SD & $4.5 \pm 0.4$ & $2.4 \pm 0.3$ & $1.86 \pm 0.14$ & 357.3 & & $<0.001$ & $<0.001$ & $<0.001$ \\
\hline Range & $3.9-5.2$ & $2-2.9$ & $1.7-2.1$ & & & & & \\
\hline erum cholesterol (m & & & & & & & & \\
\hline Mean \pm SD & $142 \pm 29$ & $404 \pm 127$ & $388 \pm 108$ & 33.7 & & $<0.001$ & $<0.001$ & $>0.05$ \\
\hline Range & 100-199 & $250-657$ & $250-601$ & & & & & \\
\hline
\end{tabular}

P1 = controls Vs MCNS.

P2 = controls Vs FSGS.

P3 = MCNS Vs FSGS. 
Table (3) showed that hemoglobin levels were significantly lower in both nephrotic groups than normal subjects $(\mathrm{P}<0.001)$ with the development of normocytic normochromic anemia. Serum neopterin was significantly higher in both nephrotic groups than control subjects $(\mathrm{P}<0.001)$ and significantly higher in FSGS group than MCNS group $(\mathrm{P}<0.001)$. Also, serum $\beta_{2^{-}}$ microglobulin was significantly higher in both nephrotic groups than control subjects $(\mathrm{P}<0.001)$, while there was no significant difference between MCNS and FSGS groups $(\mathrm{P}>0.05)$. Table (4) showed serum transferrin and serum iron were significantly lower in both nephrotic groups than control subjects and in FSGS group than MCNS group $(\mathrm{P}<0.001)$. Total iron binding capacity (TIBC) was significantly lower in both nephrotic groups than control subjects $(\mathrm{P}<0.001)$. However, there was no significant difference between MCNS and FSGS groups $(\mathrm{P}>0.05)$.
Serum ferritin was significantly higher in both nephrotic groups compared with control subjects $(\mathrm{P}<0.001)$, while there was no significant difference between MCNS and FSGS groups $(\mathrm{P}>0.05)$. The present study showed also that urinary excretion of proteins, iron, transferrin, neopterin and finally NAG were significantly higher in both nephrotic groups than control subjects $(\mathrm{P}<0.001)$ and in FSGS group as compared to MCNS group $(\mathrm{P}<0.05)$ (table 5). There were significant positive correlations between urinary iron excretion and urinary proteins $(\mathrm{r}$ $=0.915,0.924)$ and transferrin excretion $(r=0.857,0.929)$ in MCNS and FSGS groups respectively $(\mathrm{P}<0.001) \quad$ (table 6). Significant positive correlation between urinary NAG and urinary proteins excretion ( $\mathrm{r}$ $=0.811,0.909, \quad \mathrm{P}<0.001)$, urinary transferrin $(\mathrm{r}=0.777,0.851, \mathrm{P}<0.05$, $<0.001)$ and urinary iron excretion $(\mathrm{r}$ $=0.787,0.869, \mathrm{P}<0.001)$ in both MCNS and FSGS groups respectively (table 7). 
Table (3): Serum neopterin (nmol/L), Serum $\beta_{2}$-microglobulin $(\beta 2 \mathrm{M})(\mu \mathrm{g} / \mathrm{mL})$ and blood hemoglobin $(\mathrm{g} / \mathrm{dL})$, mean corpuscular volume (MCV) (fL) and mean corpuscular hemoglobin (MCH) (pg) in all studied groups.

\begin{tabular}{|c|c|c|c|c|c|c|c|}
\hline & $\begin{array}{l}\text { Control } \\
\text { group }\end{array}$ & $\begin{array}{l}\text { MCNS } \\
\text { group }\end{array}$ & $\begin{array}{l}\text { FSGS } \\
\text { group }\end{array}$ & F-test & P1 & $\mathbf{P 2}$ & P3 \\
\hline \multicolumn{8}{|l|}{$\begin{array}{l}\text { Serum neopterin } \\
\text { (nmol/L) }\end{array}$} \\
\hline Mean \pm SD & $7.5 \pm 1.8$ & $15.2 \pm 3.9$ & $24.6 \pm 4.5$ & 85.6 & $<0.001$ & $<0.001$ & $<0.001$ \\
\hline Range & $2.9-10.1$ & $10.7-22.1$ & $14.2-33$ & & & & \\
\hline \multicolumn{8}{|l|}{$\begin{array}{l}\text { Serum }(\beta 2 M) \\
(\mu \mathrm{g} / \mathrm{mL})\end{array}$} \\
\hline Mean \pm SD & $1.6 \pm 0.99$ & $6.1 \pm 1.4$ & $6.1 \pm 1.3$ & 64.4 & $<0.001$ & $<0.001$ & $>0.05$ \\
\hline Range & $0-3$ & $3.2-8$ & $3.5-8.1$ & & & & \\
\hline \multicolumn{8}{|l|}{$\mathrm{Hb}(\mathrm{g} / \mathrm{dL})$} \\
\hline Mean \pm SD & $12.2 \pm 0.4$ & $10.3 \pm 0.7$ & $10.2 \pm 0.7$ & 49.2 & $<0.001$ & $<0.001$ & $>0.05$ \\
\hline Range & $11.5-12.9$ & $9.4-11.5$ & $9-11.2$ & & & & \\
\hline \multicolumn{8}{|l|}{ MCV (fL) } \\
\hline Mean \pm SD & $80.87 \pm 3.044$ & $79.47 \pm 3.09$ & $79.2 \pm 2.93$ & 1.315 & $>0.05$ & $>0.05$ & $>0.05$ \\
\hline Range & $76-86$ & $74-84$ & $74-85$ & & & & \\
\hline \multicolumn{8}{|l|}{ MCH (pg) } \\
\hline Mean \pm SD & $26.96 \pm 1.57$ & $26.33 \pm 1.54$ & $26.73 \pm 1.34$ & 0.605 & $>0.05$ & $>0.05$ & $>0.05$ \\
\hline Range & $24-29$ & $24-29$ & $24-29$ & & & & \\
\hline
\end{tabular}

P1 = controls Vs MCNS $\quad$ P2 = controls Vs FSGS. $\quad$ P3 = MCNS Vs FSGS. 
Table (4): Serum transferrin $(\mathrm{mg} / \mathrm{dL})$, serum iron $(\mu \mathrm{g} / \mathrm{dL})$, total iron binding capacity (TIBC) $(\mu \mathrm{g} / \mathrm{dL})$ and serum ferritin $(\mathrm{ng} / \mathrm{mL})$ in all studied groups.

\begin{tabular}{|c|c|c|c|c|c|c|c|}
\hline & $\begin{array}{l}\text { Control } \\
\text { group }\end{array}$ & $\begin{array}{l}\text { MCNS } \\
\text { group }\end{array}$ & FSGS group & F-test & P1 & $\mathbf{P 2}$ & $\mathbf{P 3}$ \\
\hline \multicolumn{8}{|l|}{$\begin{array}{l}\text { Serum transferrin } \\
(\mathrm{mg} / \mathrm{dL})\end{array}$} \\
\hline Mean \pm SD & $\begin{array}{l}248.13 \pm 106.9 \\
8\end{array}$ & $\begin{array}{l}116.66 \pm 26.2 \\
9\end{array}$ & $68.27 \pm 21.51$ & 30.94 & $<0.001$ & $<0.001$ & $<0.001$ \\
\hline Range & $96-440$ & $76.20-163.40$ & $35.90-102.60$ & & & & \\
\hline \multicolumn{8}{|l|}{ serum iron $(\mu \mathrm{g} / \mathrm{dL})$} \\
\hline Mean \pm SD & $114.07 \pm 37.8$ & $79.56 \pm 35.4$ & $52.4 \pm 19.9$ & 13.99 & $<0.001$ & $<0.001$ & $<0.001$ \\
\hline Range & $70.3-190.23$ & $35.9-138.3$ & $28.1-84.09$ & & & & \\
\hline \multicolumn{8}{|l|}{ TIBC $(\boldsymbol{\mu g} / \mathrm{dL})$} \\
\hline Mean \pm SD & $317.6 \pm 48.2$ & $250.5 \pm 49.3$ & $234.1 \pm 29.3$ & 15.7 & $<0.001$ & $<0.001$ & $>0.05$ \\
\hline Range & $25.8-400.8$ & $193-350.3$ & $190.5-300$ & & & & \\
\hline \multicolumn{8}{|c|}{ Serum ferritin $(\mathrm{ng} / \mathrm{mL})$} \\
\hline Mean \pm SD & $97.5 \pm 44.7$ & $282.8 \pm 96.6$ & $291.1 \pm 87.1$ & 15.7 & $<0.001$ & $<0.001$ & $>0.05$ \\
\hline Range & $27.5-170$ & $117.6-459$ & $132.2-421.4$ & & & & \\
\hline
\end{tabular}


Table (5): Urinary proteins (g/day), Urinary neopterin ( $\mu \mathrm{mol} / \mathrm{mol}$ creatinine), Urinary $\mathrm{N}$ acetyl - $\beta$-D-glucosaminidase enzyme (NAG) $(\mathrm{U} / \mathrm{L})$, Urinary iron excretion ( $\mu \mathrm{g} / \mathrm{day})$ and Urinary transferrin (mg/day) in all studied groups.

\begin{tabular}{|c|c|c|c|c|c|c|c|}
\hline & $\begin{array}{l}\text { Control } \\
\text { group }\end{array}$ & $\begin{array}{l}\text { MCNS } \\
\text { group }\end{array}$ & $\begin{array}{l}\text { FSGS } \\
\text { group }\end{array}$ & F-test & $\mathbf{P 1}$ & $\mathbf{P 2}$ & $\overline{\mathbf{P 3}}$ \\
\hline \multicolumn{8}{|l|}{ Proteins $(\mathrm{g} /$ day $):$} \\
\hline Mean \pm SD & $0.1 \pm 0.1$ & $3.1 \pm 1$ & $5 \pm 1.1$ & 125.9 & $<0.001$ & $<0.001$ & $<0.001$ \\
\hline Range & $0.02-0.4$ & $1.8-4.9$ & $3.1-7$ & & & & \\
\hline \multicolumn{8}{|c|}{ neopterin $(\mu \mathrm{mol} / \mathrm{mol} \mathrm{Cr})$} \\
\hline Mean \pm SD & $267 \pm 75.6$ & $340 \pm 69.5$ & $422.8 \pm 35.9$ & 23.0 & $<0.001$ & $<0.001$ & $<0.001$ \\
\hline Range & $135.2-401.2$ & $210.5-450.6$ & $381.2-479.2$ & & & & \\
\hline \multicolumn{8}{|l|}{$(\mathrm{NAG})(\mathrm{U} / \mathrm{L})$} \\
\hline Mean \pm SD & $3.84 \pm 2.16$ & $8.29 \pm 2.59$ & $61.88 \pm 12.4$ & 284.24 & $<0.05$ & $<0.001$ & $<0.001$ \\
\hline Range & $0.59-7.79$ & $5.14-13.6$ & $35.4-78.6$ & & & & \\
\hline \multicolumn{8}{|l|}{ Iron $(\mu \mathrm{g} /$ day $)$} \\
\hline Mean \pm SD & $1.8 \pm 0.71$ & $22.6 \pm 0.77$ & $51.6 \pm 16.6$ & 83.809 & $<0.001$ & $<0.001$ & $<0.001$ \\
\hline Range & $0.71-2.94$ & $\begin{array}{l}12.91- \\
36.88 \\
\end{array}$ & $\begin{array}{l}27.92- \\
82.99 \\
\end{array}$ & & & & \\
\hline \multicolumn{8}{|c|}{ Transferrin (mg/day) } \\
\hline Mean \pm SD & $0.6 \pm 0.5$ & $132 \pm 74.6$ & $207 \pm 10$ & 31.3 & $<0.001$ & $<0.001$ & $<0.001$ \\
\hline Range & $0.0-2$ & $75.5-282.4$ & $80.5-418.5$ & & & & \\
\hline
\end{tabular}

Table (6): Correlations between urinary iron and urinary proteins, and urinary transferrin in MCNS and FSGS groups.

\begin{tabular}{|c|c|c|c|}
\hline \multirow{7}{*}{ 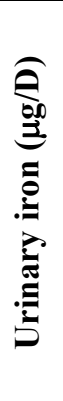 } & & Urinary proteins (g/D) & Urinary transferrin $(\mathrm{mg} / \mathrm{D})$ \\
\hline & MCNS group & & \\
\hline & $\mathrm{r}$ & $0.915^{*}$ & $0.857^{*}$ \\
\hline & $\mathrm{P}$ & $<0.001$ & $<0.001$ \\
\hline & FSGS group & & \\
\hline & $\mathrm{r}$ & $0.924 *$ & $0.929^{*}$ \\
\hline & $\mathrm{P}$ & $<0.001$ & $<0.001$ \\
\hline
\end{tabular}

* Significant. 
Table (7): Correlations between urinary N-acetyl- $\beta$-D- glucosaminidase enzyme (NAG) and urinary proteins, urinary iron and urinary transferrin in MCNS and FSGS groups.

Urinary proteins $\quad$ Urinary iron $\quad$ Urinary transferrin

$(\mathrm{g} / \mathrm{D}) \quad(\mu \mathrm{g} / \mathrm{day}) \quad(\mathrm{mg} / \mathrm{D})$

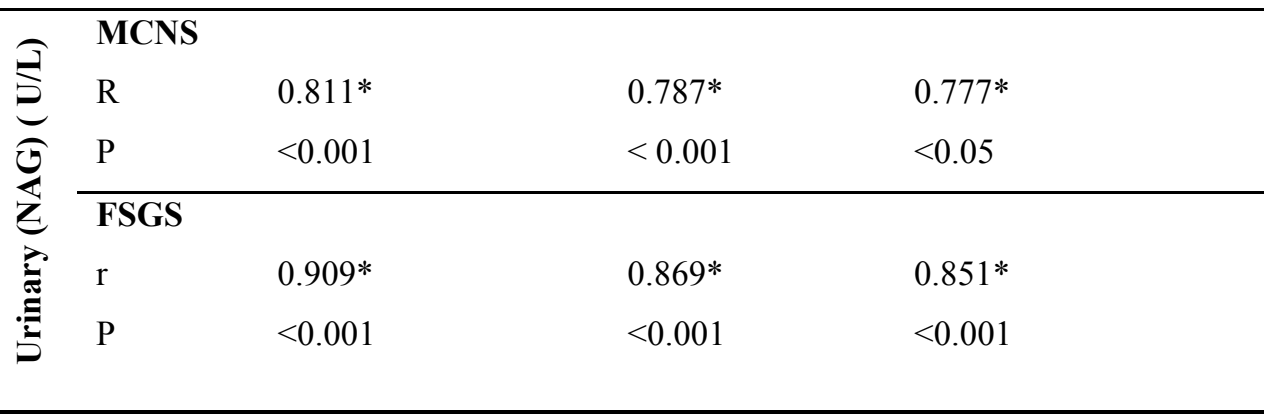

* Significant.

\section{DISCUSSION}

The idiopathic nephrotic syndrome (INS) of childhood is characterized by highly selective relapsing proteinuria which has steroid responsiveness in the majority of cases ${ }^{(24)}$. Urinary loss of proteins other than albumin in INS has been documented including carrier proteins as vitamin D-binding globulin and transferrin $^{(25)}$. Urinary losses of transferrin can reduce serum iron concentrations and consequently cause iron deficiency anemia which is a feature of chronic nephrotic syndrome in adults and children and have with oxidant a big role in progressive renal injury in INS ${ }^{(26,27)}$.

In the present study, all cases of NS suffered from normocytic normochromic anemia and this could be explained by either urinary loss of erythropoietin, extravasation, expanded distribution volume and hemodilution $^{(3,28)}$ or as a result of increased urinary losses of transferrin and iron ${ }^{(29,30)}$.

In the present study, serum transferrin, serum iron and TIBC were significantly lower in INS patients than control subjects and it was significantly lower in FSGS patients. Urinary transferrin and urinary iron excretion were significantly higher in INS patients than control subjects and it was significantly higher in FSGS patients than MCNS patients. There were significant positive correlations between urinary iron excretion and urinary proteins and transferrin excretion in both nephrotic groups of children. This could be explained by proteinuria with subsequent transferrinuria, as transferrin is the primary vehicle of iron, so transferrinuria followed by iron depletion as evidenced by $\mathbf{L u}$ et $\boldsymbol{a l}$. (31). The difference in iron excretion between MCNS and FSGS patients is 
related to the increase in proteins and transferrin excretion in FSGS group than MCNS group ${ }^{(25)}$.

The importance of iron in renal injury is derived from the ease with which iron is reversibly oxidized and reduced. Although, this is essential for its metabolic functions, it also makes iron potentially hazardous because of its ability to participate in the generation of such powerful oxidant species as hydroxyl radicals and/or reactive iron-oxygen complexes, such as ferryl and perferryl ion (27). Iron also has a major role in the initiation and propagation of lipid peroxidation $^{(32)}$. Cooper et al. (33) suggested that glomerular injury from diverse causes impairs glomerular permeability and selectivity, thus leading to leakage of proteins, including transferrin, into the urinary space. Urinary transferrin provides a source of iron ${ }^{(27)}$. The binding of iron to transferrin is $\mathrm{pH}$ dependent. At $\mathrm{pH}$ less than 6.5, iron dissociates from transferrin in urine, thus providing a source of iron that could act on renal tubular epithelial cells or be absorbed into the tubules. The precise cellular mechanisms by which oxidants and iron participate in renal disease progression are not known. However, oxidants and iron have many cellular effects that are potentially important in tubulointerstitial damage, fibrosis, and matrix accumulation. For example, it is well established that oxidants and iron have an important role in cellular injury and cell death, including apoptosis. Thus, they could conceivably have a role in tubular atrophy and loss of cells, which is a common feature of progressive renal disease. In addition, lipid peroxidation has been shown to be important in the induction of collagen gene expression and may thus contribute to renal fibrosis $(\mathbf{2 7 , 3 2 )}$

Neopterin (NP) production has been linked to activation of cellmediated immunity ${ }^{(34)}$. It is excreted in an unchanged form via the kidneys. Serum level of neopterin above $10 \mathrm{nmol} / \mathrm{L}$ is regarded as elevated. The levels of neopterin in body fluids are elevated in infections, autoimmune diseases, malignancies, allograft rejection, cardiac and renal failure, coronary artery disease and myocardial infarction. Neopterin measurements not only provide an insight into the present state of cellmediated immune response, but also allow monitoring and prognosis of disease progression ${ }^{(35)}$. Association of cellular immune disorders with the pathogenesis of nephrotic syndrome has been proposed in minimal change disease and in other types of glomerulonephritis ${ }^{(36)}$.

The results of our study showed that serum ferritin, serum neopterin and urinary neopterin were significantly higher in both MCNS and FSGS patients than control subjects. Moreover, they were significantly higher in FSGS group than MCNS group. Our results were in agreement with Kotanko et al. ${ }^{(37)}$ and Lhee et al. ${ }^{(38)}$ who found significant high values of serum and urinary neopterin in nephrotic patients than healthy subjects. However, there was no difference between MCNS and FSGS patients, and Kotanko et al. ${ }^{(37)}$ and Lhee et al. ${ }^{(38)}$ explained that by abnormal monocyte/macrophage function as well as disturbed T-cellmediated immunity, regardless of 
basic type of glomerular lesion and regardless whether abnormal cellular immunity is the cause or consequence of nephrotic state.

Also, the current results were in agreement with Dietmar et al. ${ }^{(39)}$ who explained high serum ferritin by increased serum neopterin levels due to chronic activation of cellular immunity which was obviously associated with shift of iron from the circulation into its storage sites. Pagel et al. ${ }^{(\mathbf{4 0})}$ showed that activated macrophages may not only inhibit the synthesis of erythropoietin by generating cytokines and reactive oxygen species, but also by the release of pteridines so, high concentrations of pteridines in renal tissue may aggravate the anemia of inflammation. Kemper et al. ${ }^{(41)}$ stated that despite reduction of serum iron during relapse, iron stores as assessed by serum ferritin and hematological parameters reflecting iron status which did not change during proteinuria, probably because remission can be achieved quickly by administration of steroids limiting renal transferrin and iron loss. Machiko et al. ${ }^{(42)}$ showed that, in nephrotic patients, normocytic normochromic anemia was the presentation and it was due to erythropoietin deficiency as serum iron and serum ferritin levels were normal. In contrast, Sofia et al. (28) reported that serum ferritin levels were significantly lower in nephrotic children with anemia. However, iron supplementation led to normalization of ferritin concentrations but did not result in a significant increase in hemoglobin levels. $\beta 2-$ microglobulin $(\beta 2-\mathrm{M})$ is an
$\mathrm{kDa} \quad$ non-glycosylated polypeptide composed of 100 amino acids. It is the invariant chain of the major histocompatibility $(\mathrm{MCH})$ class I molecules on the cell surface of all nucleated cells. Its best-characteristic function is to interact with and stabilize the tertiary structure of MHC class I $\alpha$-chain ${ }^{(21)}$. Free $\beta 2 \mathrm{M}$ is found in body fluids under physiologic conditions as a result of shedding from cell surfaces or intracellular release. $\beta 2 \mathrm{M}$ is almost exclusively catabolized within the kidney. $95 \%$ to $100 \%$ of circulating $\beta 2 \mathrm{M}$ is eliminated through glomerular filtration $^{(\mathbf{4 3})}$. The determination of $\beta 2$ microglobulin in serum or plasma aids in the clinical assessment of activation of the cellular immune system and is considered as a tumor marker ${ }^{(44)}$. In the kidney, $\quad \beta 2-\mathrm{M}$ is filtered glomerularly and reabsorbed tubularly. A measurement of $\beta 2-\mathrm{M}$ in serum and urine allows a differentiation between an activation of the lymphatic system and renal filtration disorders ${ }^{(21)}$.

The results of our study showed that there was a significant higher level of serum $\beta 2-\mathrm{M}$ in both MCNS and FSGS groups than control subjects. Idiopathic nephrotic syndrome might be secondary to a disorder of T-lymphocyte function so elevation of serum $\beta 2-\mathrm{M}$ occurs as a result of activation of cellular immune system (2, 44). Also, low-molecular weight serum proteins; Beta-trace protein (BTP), $\beta 2$-microglobulin and cystatin- $C$ had higher diagnostic accuracy than serum creatinine for identification of moderately impaired 
glomerular filtration rate in children ${ }^{(2,}$ 21, 44). The association of increased serum neopterin with increased serum $\beta 2$-microglobulin in our study supports the theory of disturbed cellular immune system ${ }^{(2)}$.

In various human glomerular diseases, a correlation has been demonstrated between extent of proteinuria, tubulointerstitial damage (TID) and progression to chronic renal failure ${ }^{(45)}$. However, a direct demonstration of a toxic effect on the tubular cells by sustained and protracted proteinuria in chronic glomerular diseases in man is still lacking, and this explains the interest in the search for reliable markers of tubular damage in the urine of patients with glomerular diseases. N-Acetyl- $\beta$ $D$ - glucosaminidase (NAG) is a urine enzyme of the hydrolase class, which is abundant in the lysosomes of proximal tubular cells ${ }^{(46)}$. Urinary NAG in healthy subjects represents the amount physiologically released by the renewal of renal tubular cells and it increases after exposure to various toxic substances, such as nephrotoxic drugs and in various human glomerular diseases, including diabetic nephropathy. Increased urinary NAG in glomerular diseases is due to increased release by the renal tubular cells and not due to increased filtration across the damaged glomerular capillary wall ${ }^{(47)}$.

The results of our study showed that urinary NAG excretion was significantly higher in MCNS and FSGS patients than control subjects and it was significantly higher in FSGS patients. Also, significant positive correlations between urinary NAG and urinary proteins excretion, urinary transferrin and urinary iron excretion were present in both MCNS and FSGS groups. This finding could be explained by the transit of an excessive amount of protein through the glomeruli and tubules which is toxic to the kidney in a dose dependent fashion which lead to increased NAG release by the renal tubular cells ${ }^{(48)}$. Our results were in agreement with Bazzi et al. ${ }^{(47)}$ who confirmed that the level of NAG excretion may be a useful noninvasive and easily repeatable test for assessing an initial malfunction or damage of the proximal tubular epithelial cells in the early stages of potentially progressive diseases. Skalova $^{(49)}$ stated that the determination of urinary NAG provides a very sensitive and reliable indicator of renal damage, such as injury or dysfunction due to diabetes mellitus, nephrotic syndrome.

Conclusion: The results of the present study could explain the common occurrence of normocytic normochromic anemia in idiopathic nephrotic syndrome patients (INS) despite the increased urinary losses of iron and transferrin. Moreover, iron has been suggested to be dissociated from transferrin in the kidney in both groups of nephrotic syndrome. This is accompanied by increase in reactive iron species which could cause tubulointerstitial injury through the formation of free radicals with subsequent renal damage and chronic renal failure in children with FSGS.

This renal injury in nephrotic children is manifested by increased urinary NAG excretion. So, measuring urinary protein, urinary iron and urinary NAG could be important for 
follow up and prediction of the prognosis in children with idiopathic nephrotic syndrome. Increased both serum and urinary neopterin and serum $\beta_{2}$-microglobulin can be used as markers of immune activation in nephrotic syndrome, but is it a cause of development of idiopathic nephrotic syndrome, or a result of it!? This needs further evaluation.

\section{REFERENCES}

1. Davis I.D. and Avner E.D. (2004): Glomerular disease. In Richard E. Behrman, Robert M. Klicgman, Hal. B Jenson (eds). Nelson Textbook of Pediatrics $17^{\text {th }}$ edition, Chapter 519; Saunders Philadelphia, Pennsylvania. PP. 1753.

2. Eddy A.A. and Symons J.M. (2003): Nephrotic syndrome in childhood. The lancet 362: 629639.

3. Vaziri N.D. (2001): Erythropoietin and transferrin metabolism in nephrotic syndrome. Am. J. Kid. Dis., 36(1): 1-8.

4. Block B., Popovici T., Chouham S., Levin M.J., Tuil D. and Kahn A. (1987): Transferrin gene expression in choroid plexus of the adult rat brain. Brain Res. Bull., 18: 573-576.

5. Ponka P., Beaumont $C$. and Richardson D.R. (1998): Function and regulation of transferrin and ferritin. Semin. Hematol., 35: 35-54.

6. Shaw A.C. (1991): Serum Creactive protein and neopterin concentrations in patients with viral or bacterial infection. J. Clin. Pathol., 44:596-599.

7. Charles A.J., Paul T., Mark W. and Mark J.S. (eds) (2001): Antigen recognition by T-cells: In immunobiology $5^{\text {th }}$ edition, Chapter 3, Garland Publishing, Churchill Livingstone. PP. 112.

8. Louis J.M., Reichert-Robert A.P. and Koene-Jack F.M. (1998): Prognostic factors in idiopathic membranous nephropathy, Am. J. Kid. Dis., 31(1): 1-11.

9. Stirling B. (1989): Enzymuria as a marker of renal injury and disease. Pediatrics 62:60-75.

10. Powell S.C., Scaro J., Wilson E. and Shihab Z.K. (1983): Beta 2microglobulin: methods and clinical applications. Science 10:225-245.

11. Watanabe N., Kamel S., Ohkubo A., Yamanaka M., Ohsawa S., Makino K. and Tokuda K. (1986): Urinary protein as measured with a pyrogallol red-molybdate complex, manually and in a Hitachi 726 automated analyzer. Clin. Chem., 32(80): 1551-1554.

12. Gornall A.G., Bardawill C.J. and David M.M. (1949): Determination of serum proteins by means of the biuret reaction. J. Biol. Chem., 177:751-766.

13. Johnson A.M., Rohlfs E.M. and Silverman L.M. (1999): Proteins. In: Burtis CA, Ashwood ER. Editors. Tietz Textbook of Clinical Chemistry. $3^{\text {rd }}$ ed. Philadelphia: WB. Saunders Company; PP. 477-540.

14. Patton C.J. and Crouch S.R. (1977): Spectrophotometric and 
kinetics investigation of the Berthelot reaction for the determination of ammonia. Anal. Chem., 49(3):464-469.

15. Rartels $H$. and Böhmer $M$. (1971): Micro-determination of creatinine. Clin. Chim. Acta 32(1): 81-85

16. Rifai N., Bachorik P.S. and Albers J.J. (1999): Lipids, lipoproteins and apolipoproteins. In: Burtis CA, Ash wood ER. (editors), Tietz Textbook of Clinical Chemistry ( $3^{\text {rd }}$ ed.). Philadelphia, WB. Saunders Company, PP. 809-61.

17. Meschler A.L. and Muriam S.I. (1988): Transferrin and the growth-promoting effect of nerves. Int. Rev. Cytol., 110:1-26.

18. Garčic A. (1979): A highly sensitive, simple determination of serum iron using chromazurol B. Clin. Chim. Acta 94(2): 115-119.

19. Halliday J.W., McKeering L.V., Tweedale R. and Powel LW. (1977): Serum ferritin and its clinical significance. Br. J. Clin. Path., 27: 652.

20. Ramsay W.N.M. (1957): The determination of the total ironbinding capacity of serum. Clin. Chim. Acta 2(3):221-226.

21. Odell R.A. (1991): Beta-2 microglobulin kinetics in endstage renal failure. Kidney Int., 39: 909-919.

22. Westermann J., Thiemann F., Gerstner L., Kozak I., Bertsch T. and Krüger C. (2000): Evaluation of a new simple and rapid Enzyme. Linked Immunosorbent Assay kit for neopterin determination. Clin. Chim. Lab. Med., 38(4): 345-353.
23. Yakata M. (1983): Evaluation of urinary N-acetyl- $\beta$-Dglucosaminidase enzyme. Jap. J. Clin. Pathol., (Suppl.,) (56): 90.

24. Baratt M. and Clark G. (1995): Minimal change nephrotic syndrome and focal segmental glomerulosclerosis. In: Holliday MA, Baratt TM, Avner ED. (eds) Pediatric Nephrology ( $3^{\text {rd }}$ Ed). Williams and Wilkins, Baltimore, PP. 767-787.

25. Berthil H.C., Prinsen M.T., Morique G.M., Der Velden D. S., Kaysen G. A. and Helma W.H.C.. (2001): Transferrin synthesis is increased in nephrotic patients insufficiently to replace urinary losses. J. Am. Soc. Nephrol., 12: 1017-1025.

26. Hancock E., Onstad W. and Wolf L. (1975): Transferrin loss into the urine with hypochromic microcytic anemia. Am. J. Clin. Pathol.; 65: 73-78.

27. Sudhir V.S. (2001): Role of iron in progressive renal disease. Am. J. Kid. Dis., 37(1): S30-S33.

28. Sofia F., Rachel BC., Nurit A., David R., Hanna S., Yigal S. and Yaacov F. (2001): Erythropoietin deficiency causes anemia in nephrotic children with normal kidney function. Am. J. Kid. Dis., 37(N4):736-742.

29. Howard R.L., Buddingtion B. and Alfrey A.C. (1991): Urinary albumin, transferrin and iron excretion in diabetic patients. Kidney Int., 40:923-926.

30. Shibasaki T., Misawa T., Matsumoto H., Abe S., Nakano H., Matsuda H., Gomi H, Ohno I., Ishimoto F. and Sakai $O$. (1994): Characteristics of anemia 
in patients with nephrotic syndrome. Nippon Jinzo Gakkai Shi 36(8): 896-901.

31. Lu H.Z., Yuan Y.S., Zhang W.M., Liu D. and Kuang H.Y. (2006): Concentrations of serum iron and transferrin in children with nephrotic syndrome. Chin. J. Contemp. Pediatr., 8(6):467-469.

32. Halliwell B. and Gutteridge J.M.C. (1990): Role of free radicals and catalytic metabolites in human disease: An overview. Methods Enzymol., 186: 1-85.

33. Cooper M.A., Buddington B., Miller N.L. and Alfrey A.C. (1995): Urinary iron speciation in nephrotic syndrome. Am. J. Kidney Dis., 25(2): 314-319.

34. Huber C., Batchelor J., Fuchs D., Hausen A. and Lang A. (1984): Immune response associated production of neopterin release from macrophages primarily under control of interferon gamma. J. Exp. Med., 160:306-310.

35. Berdowska A. and ZwirskaKorezola K. (2001): Neopterin measurements in clinical diagnosis. J. Clin. Pharm. Ther., 26 (5): 319-29.

36. Matsumoto K., Ohi H. and Kanmatsuse K. (1998): Interleukin-12 upregulates the release of vascular permeability factor by peripheral blood mononuclear cells from patients with lipoid nephrosis. Nephron 78: 403-409.

37. Kotanko P., Margreiter R., and Pfaller W. (2000): Urinary Nacetyl- $\beta$-D-glucosaminidase and neopterin aid in the diagnosis of rejection and acute tubular necrosis in initially nonfunctioning kidney grafts. Nephron 84: 228-235.

38. Lhee H.Y., Kim H., Joo K.J., Jung S.S. and Lee K.B.(2006): The clinical significance of serum and urinary neopterin levels in several renal diseases. J Korean Med Sci., 21(4):678-82

39. Dietmar F., Günter W., Gilbert R., and Helmut W. (1992): The role of neopterin as a monitor of cellular immune activation in transplantation, inflammatory, infectious, and malignant diseases. Critical Reviews in Clinical Laboratory Sciences 29(3, 4): 307-341.

40. Pagel H., Fandrey J., Schobersberger W., Fuchs D. and Jelkmann W. (1999): Effects of neopterin and 7,8dihydroneopterin on hypoxiainduced renal erythropoietin production. Eur. J. Hematol., 62(5): 341-5.

41. Kemper M.J., Bello A.B., Altrogge H., Timmermann K., Ludwig K. and Müller-Wiefel D.E. (1999): Iron homeostasis in relapsing steroid-sensitive nephrotic syndrome of childhood. Clin. Nephrol., 52 (1): 25-29.

42. Machiko Y., Minoru K., Yoshiyuki T., Kouichi T., Katsumi M., Nobuyoshi T., Seiko K., Masao I. and Satoshi U. (1999): Simultaneous improvement of minimal-change nephrotic syndrome and anemia with steroid therapy. Nephron 81: 84-88.

43. Xie J., Wang Y., Muta E., Freeman I., Barlogie B. and Yi Q. (2003): $\beta_{2}$-Microglobulin as a 
negative regulator of the immune system: high concentrations of the protein inhibit in vitro generation of functional dendritic cells. Blood 101(10): 4005-4012.

44. Ljunggren H.G. (1992): Role of $\beta 2$-microglobulin in cancer. Cancer J., 5: 308-315.

45. D'Amico G. (2000): Natural history and prognosis of chronic primary glomerulonephritis. In: El Nahas AM ed. Mechanisms and Clinical Management of Chronic Renal Failure, $2^{\text {nd }}$ edition, Oxford University Press, Oxford. PP 241-264.

46. Claudio B., Concetta P. and Virginia R. (2002): Urinary Nacetyl- $\beta$ glucosaminidase excretion is a marker of tubular cell dysfunction and a predictor of outcome in primary glomerulonephritis. Nephrol. Dial. Transplant., 17: 1890-1896.
47. Bazzi C., Petrini C., Rizza V., Arrigo G., Napodano P., Paparella $M$. and D'Amico G. (2002): Urinary $N$-acetyl- $\beta$ glucosaminidase excretion is a marker of tubular cell dysfunction and a predictor of outcome in primary glomerulonephritis. Nephrol. Dial. Transplant., 17: 1890-1896.

48. Kuzniar J., Marchewka Z., Lembas-Bogaczyk J., Kuzniar T.J. and Klinger M. (2004): Etiology of increased enzymuria in different morphological forms of glomerulonephritis. Nephron. Physiol.; 98(1): 8-14.

49. Skalova S. (2005): The diagnostic role of urinary $\mathrm{N}$ acetyl-beta-D-glucosaminidase

(NAG) activity in the detection of renal tubular impairment. Acta Medica 48(2): 75-80. 


\title{
أهمية تقييم نسبة الحديد والترانسفرين فى البول فى الأنواع الهستوباثولوجية الثائعة فى متلازمة النفروزس الابتدائية فى الأطفال
}

\author{
غادة /حمد عبدالعلبم ، *ناجى محدد أبو الهنا، *عمرو محد ز زعبر،

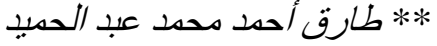

قسم الكيمياء الحيوية الطبية، *قسم الاطفال،*** قسم الباثولوجيا ـ كلية الطب ـ جامعة طنطا

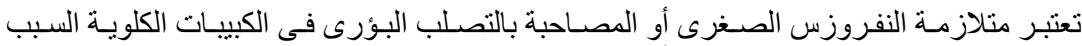

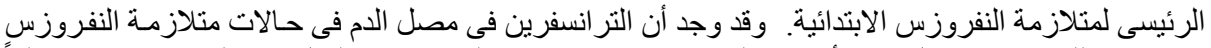

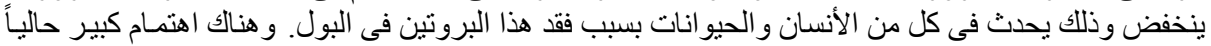

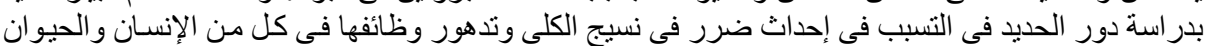

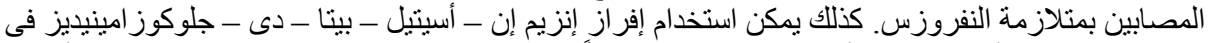

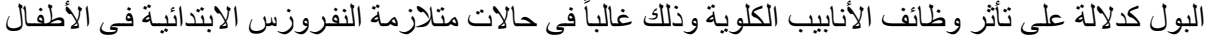

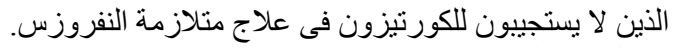
الهزف من البحث: إنين

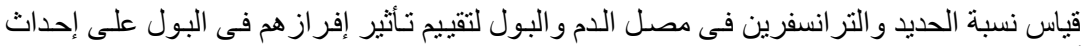

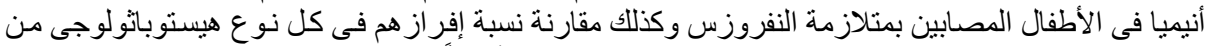

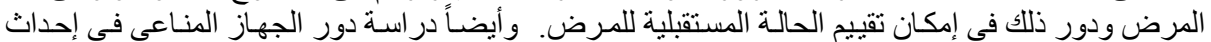

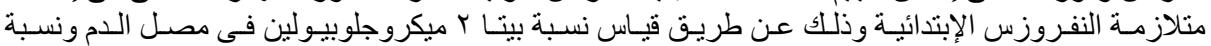

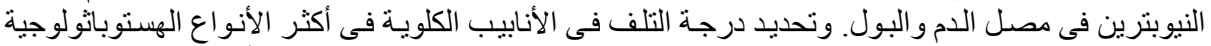

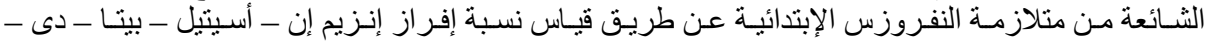

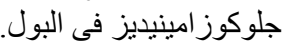

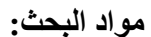

تم إجر اء هذا البحث على خمسة وأربعين طفلاً من الجنسين وتم تقسيمهم إلى مجمو عتين: المجمو عـة

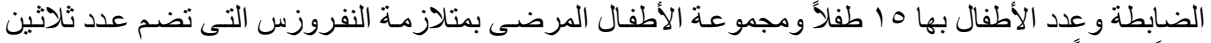

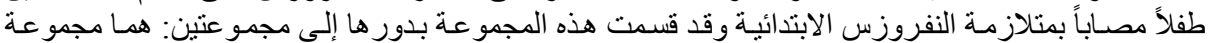

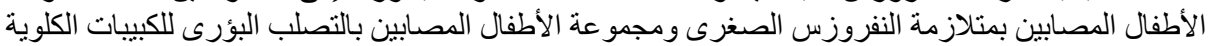

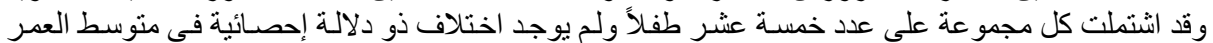
ونوع الجنس بين المجمو عات الثناثة تم أخذ التاريخ المرضى للأطفال المدرجين تحت هذه الدراسة وتم فحصهم فحصاً إكلينيكياً كاملاً وتم

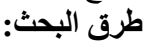
عمل الأبحاث المعملية التالية لكل الأطفال:

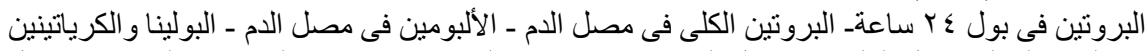

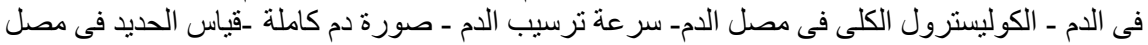

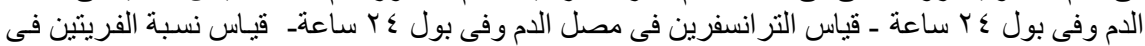

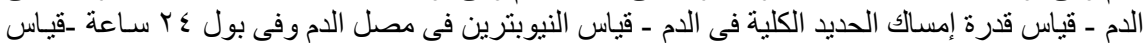

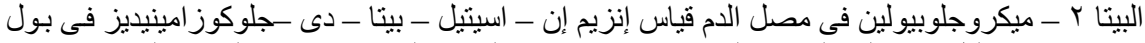

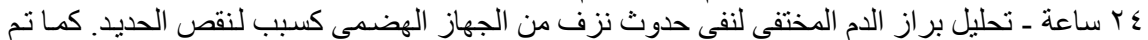

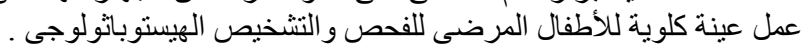

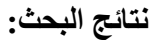

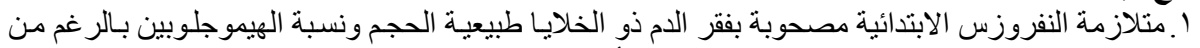

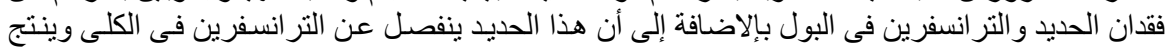


عنه سلالات من الحديد المتفاعل الذى يتسبب فى إحداث تلف فى النسيج و الأنابيب الكلويـة عن طريق تكون مشتقات حرة.

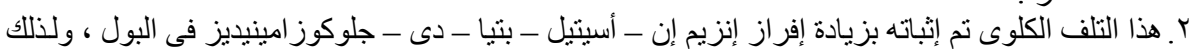

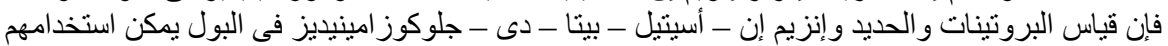

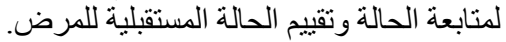

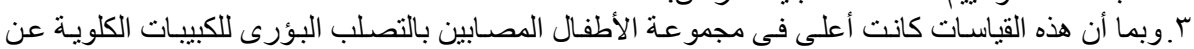

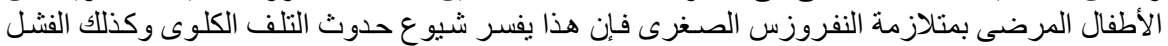

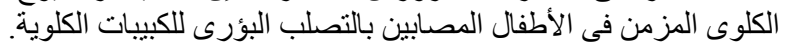

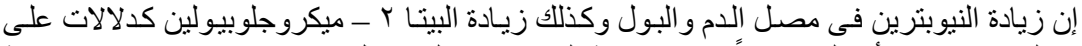

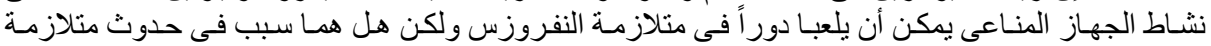

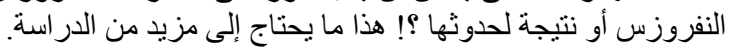

